\title{
The Role of Anti-Americanism in the Contemporary
}

\section{European Identity Building (Note 1)}

\author{
Qin Pang \\ Lecturer, Guangdong University of Foreign Studies, China \\ $\&$ \\ Full-time Research PhD Candidate \\ Department of Asian and International Studies \\ City University of Hong Kong, Hong Kong \\ E-mail: pampkinpang@gmail.com
}

Received: May 1, $2011 \quad$ Accepted: May 17, $2011 \quad$ doi:10.5539/res.v3n1p94

\begin{abstract}
This paper argues that the surging anti-Americanism in Europe since 2003 has helped strengthen the European identity by shaping a political, economic, social and cultural "Other" — the U.S.—-among the Europeans. It first surveys the contemporary European anti-Americanism including its historical roots, and then moves on to analyze its role in the current European identity building through examining two typical cases and empirical data from the Eurobarometer.
\end{abstract}

Keywords: Anti-Americanism, European identity, “Other”, European integration, American foreign policy

\section{Introduction}

European identity refers to the beliefs and feelings that one has towards "Europe" to which they see themselves belonging to (Kenrick, Neuberg, \& Cialdini 2007). It has always been of crucial importance for the EU integration process, since without a common European identity, EU is nothing but a union of common interests. Like other human group identities, the European identity heavily relies on the "existence" of non-European "Others" (out-groups), because if there are no "Others" (or "out-groups"), there will be no "Self" (or "in-groups)" (Erikson 1963). The European identity, in its formation, involves many "Others", and one of them is notably, the US. And this paper explores the role of the rising anti-Americanism since 2003 in the contemporary European identity building and contends that the swelling anti-Americanism has consolidated the European identity by accentuating the political, economic, social and cultural differences between the US and Europe.

\section{The Evolution of European Anti-Americanism and Its Role in European Identity Building}

Anti-Americanism refers to the negative attitudes towards the U.S. and American society including its social, economic and political institutions, dislike of American people, manners, and even values and rejection of American foreign policies (Hollander 1992: 334-335).

The earliest anti-Americanism can be traced back to the mid-eighteenth century, even before the founding of the United States. Its main content was that all living things in the Americas were not only inferior to those found in Europe but also in a condition of decline. The French anthropologist Comte de Buffon, argued that North America's native population was particularly retarded and "degenerate" and that this physiological and psychological inferiority somehow transferred onto the new European immigrants who, too, regressed once they reached America (Buffon, 1807: 306 - 352). Another proponent of the degeneracy thesis at the time was the Dutch naturalist Cornelius de Pauw who decried the existence of America as "the worst misfortune" that could have happened to all humanity, upsetting even the New World's dogs who - according to de Pauw - never barked (Pauw, 1974: II).

Romantic thinkers in the 19th century charged that the American political institution was inferior, holding that the institution which was based on Enlightenment notion of Nature with the aid of Reason would not last. 
According to Joseph de Maistre, Not only was the Declaration (of Independence) based on flawed premises, but so too was the U.S. Constitution with its proposition that men could establish a new government. "All that is new in (America's) Constitution" he warned, "is the most fragile thing in the world."(Ceaser, 2003: 9) And they went on to point that nothing constructed on the thin soil of Enlightenment principles could sustain a genuine culture. There was only a dull materialism: "The American knows nothing; he seeks nothing but money; he has no ideas". (Ceaser, 2003: 9)

From the late 19th century to the middle 20th, anti-Americanism targeted at the "inferior American culture", charging it completely lacking any sense of history and individuality. Nietzsche was an early exponent of this view, arguing that America sought the reduction of everything to the calculable and said: "The breathless haste with which they [the Americans] work - the distinctive vice of the new world - is already beginning ferociously to infect old Europe and is spreading a spiritual emptiness over the continent." (Ceaser, 2003: 12) Heidegger criticized the soulless American culture, and regarded it as the very embodiment of the reign of the ersatz, encouraging the absorption of the unique and authentic into the uniform and the standard (Ceaser, 2003:15). After the World War II, the anti-Americanism was mainly embraced by the political Left in Western Europe who went on to censure the rootless American culture which is full of materialism and libertinism.

The afore-mentioned anti-Americanism in European history constructed an image of the "inferior" US in natural conditions, political institutions and culture. As Edward W. Said has put it, "the self-identity construction involves recognition of "Others" who are contrary to self, and cognition, explanation and re-explanation of the characters that are different from ours." (1994: 426 - 427) The "inferior" American image shaped by anti-Americanism is such a way for the Europeans to cognize and explain the characters of American culture that are distinctive from the Europeans. Through such an ethno-centralistic explanation, the European identity was built as it not only provides an "un-European" "Other", but also a greatly enhanced European sense of cultural superiority.

The contemporary anti-Americanism, inheriting its old tradition of criticizing American history and culture, went on developing and has taken a variety of new forms. In the following section, the author will categorize the contemporary European anti-Americanism into three groups based on the combined views of Russell Berman and Andrei Markovits (Berman, 2004: 42-44.\& Markovits, 2005: 54).

The first category focuses on the strong sense of European cultural superiority. This thought enjoys great popularity among the political and cultural elites in Europe. They deem the US culture as commodified and vulgar as opposed to the refinement and grace of European culture; and this can be seen clearly in their resistance of Hollywood movies and American fast food. Besides, the American mass culture is often seen as either too prudish or too prurient, while the European is savvy and wise.

The second group accuses the United States of being retrograde in its social institutions and systems. In moral and religion areas, the US acts as the purveyor of the death penalty and of religious fundamentalism, as opposed to European abolition of the death penalty and adherence to an enlightened secularism; in economic and social welfare field, America was seen as the bastion of what former German Chancellor Helmut Schmidt called "predatory capitalism" and of mass incarceration, as opposed to Europe as the home of the considerate welfare state and of rehabilitation. The former French Foreign Minister Hubert Vedrine criticized the American "ultraliberal market economy, rejection of the state, non-republican individualism" and claimed that these were the "Kulturkampf (cultural differences) between Europe and America". (Lawday, 2001) Moreover, many Europeans also believed there were great differences between EU and the US in education, environment protection and social security and most of them believed that EU did better than the US (see table 1).

The third category targets at American foreign policies and actions. As early as in 1983, the European opposition to American foreign policy has been shown in a public poll conducted in six European countries. The majority of people in five of the six surveyed countries agreed that the military existence of the US increased the possibility of war. (kohut, 2006: 24) In 2003, 53\% of the surveyed Europeans believed that the US constituted threats to the world peace (The Pew Research Center, 2003). After the end of Cold War, there have been increasing discrepancies between Europe and the US in world affairs, including European opposition to American unilateral policies and actions(like American launch of the Iraq War), dissatisfaction with American performance in environment and human rights protection (especially American withdrawal of The Kyoto Protocol, and its abuse of Iraq War prisoners). After the Iraq War, the American image in major European countries slipped considerably (see table 2).

The three kinds of anti-Americanism depict an "Other's" image in culture, socio-economy and diplomacy for the Europeans. This is an image of the "un-European" U.S., a country of ultraliberal market capitalism, without 
profound culture, being unsound in welfare, education and social security institution building. It pushed unilateralist foreign policies, ignored environment and human rights protection, posing threats to world peace. Through this mirror (of the US), the European acquired a clearer idea of their own "distinctive characters": rich in historical and cultural traditions, more egalitarian in society, more environment-protecting and peace-loving. The recognition of their "distinctiveness" helps provide a clear self-image for the Europeans. On top of this, what anti-Americanism portrayed is an inferior, retrograde, irresponsible and arbitrary America, through which the European sense of pride and confidence in Europe can be easily established. All these, without doubt, contributed to the European identity building. And this enhanced identity can be seen in their joint efforts in resisting American movies, achieving independent diplomacy, and establishing European independent and quick-response army.

Insert Table 1 and 2 Here

\section{Two Case Studies of Analyzing Anti-Americanism in European Identity Building}

In the following sections, two cases will be studied to show the important role that the U.S. played as "Other" in establishing European identity in both grass-roots and elite government level.

\section{Case Study I: the February 15, 2003 Anti-Iraq War Protest across the Europe}

The first case is about grass-roots leveled European identity building and it is the February 15, 2003 anti-Iraq War protest across the Europe. On that day, from London to Rome, from Paris to Madrid, from Athens to Helsinki, from Berlin to Barcelona, people went on streets to oppose the impending American attack of Iraq. The number of European protesters was unprecedented, with that in Rome around 3 million people which was listed in the 2004 Guinness Book of World Records as the largest anti-war rally in history. Many other cities, like London, Berlin and Madrid, saw the largest demonstrations for several decades. "Never before in European history did so many millions of Europeans unite in public on one day for one purpose." (Markovits, 2005: 56) And people joining the protest were from wide social spectrum, including country folk and lecturers, even hairdressers and poets. (Ferguson, 2003) The demonstration bespoke the then soaring Anti-Americanist sentiments in Europe. Large majorities surveyed believed that America paid little or no attention to their country's interests in making its foreign policy decisions. This opinion was most prevalent in France (84\%). Even in Great Britain, the alliance of the US, 61\% held the same opinion (The Pew Research Center, 2004).

And American motives of launching the war were widely suspected. "This war is solely about oil. George Bush has never given a damn about human rights," London Mayor Ken Livingstone said (CNN online news, 2003). In a poll conducted later in March 2003, it showed that compared with one year before, there was a growing percentage of Europeans wanting foreign policy and security arrangements independent from the U.S. and that across Europe, there was considerable support for the European Union to become as powerful as the United States (The Pew Research Center, 2004).

This is a case in point to illuminate the positive role of Anti-Americanism in European identity building. With strong disagreements with American unilateral foreign policies, tens of millions of Europeans walked on the street and joined together to oppose the Iraq War. Through the united and uniform actions against American hegemonism, the Europeans acquired a shared sense of "we" who have common interests and values, and this laid solid foundation for European identity building. Some European commentators even claimed the protest as birth of a nascent "European nation". Dominique Strauss-Kahn made it clear in an article in Le Monde "On Saturday, February 15, 2003, a nation was born on the streets. This nation is the European nation." (Strauss-Kahn, 2003) On May 31, 2003, Jügen Habermas published an article on Europe's rebirth after the protest in the Frankfurther Allgeneine Zeitung.

\section{Case Study II: EU's Following Google's Lead with Online Library}

The second case which demonstrates the important role of the US as "Other" played in eliciting self-identification among European elites is "EU's following Google's lead with online library". In December 2004, the American Google company announced the Google Print Library Project, which aimed at digitally scanning millions of books from the collections of five major research libraries (Note 2) and make them searchable online through Google's popular search engine. This move raised concerns in a number of European countries regarding the ever-increasing dominance of the English language and American corporations on the internet and global culture.

In order to counterattack the Project, Jean-Noë Jeanneney, president of the National Library of France, issued a call to other European librarians to establish an European digital library of their own. Failure to do so, he argued in newspaper editorials and public statements, would lead to American cultural hegemony in scholarship (Labi, 
2005). His plan soon received active support. In April, 2005, the French, Italian, Spanish, German, Polish and Hungarian leaders sent a letter to European Commission President José Manuel Barroso and the then European Council President Jean-Claude Juncker, saying "The heritage of European libraries is unequalled in richness and diversity,' "but if it is not digitized and made accessible online, this heritage could, tomorrow, fail to fill its just place in the future geography of knowledge"(eGovernment News, 2005). The proposal was welcomed by the president, Jean-Claude Juncker, who said "We have to act" and " I say 'yes' because Europe must not submit in the face of virulent attacks from others." (eGovernment News, 2005) It also soon received the support of the national libraries of 19 EU Member States. In October, the European Commission formally announced its plan of European Library to put Europe's cultural heritage on the internet, and said "without a collective memory, we are nothing, and can achieve nothing. It defines our identity."(out-law.com, 2005)

This case exemplified the stimulating role of the US in fostering common European identity in the government level. The European cultural elites were clear about their common cultural and historical heritage which was part of their cultural identity. And clearly they had strong sense of pride in them, claiming "the heritage of European libraries is unequalled in richness and diversity". However, this kind of cultural identity remained mild when there were no "Other's" intrusion. In this case, the US planned to expand its culture and take lead in the future online knowledge competition, which triggered the European worry that they might fall behind the US. Driven by it, the European nations decided to unite and fight against the American cultural imperialism. During the process, the Europeans clearly defined who we are through distinguishing "Us" from "Other", here the US, hence, their common identity was further established and reinforced.

\section{The Empirical Analysis}

The European identity involves not only the individual identity possessed by "Europe" as an "individual", which has been discussed in the previous sections, but also the social identity held by individual Europeans. As for the social identity building, anti-Americanism also played an important role. According to the social identity theory of sociologists Tajfel and Turner, individual human being will classify people (including himself/herself) into different groups and identify himself/herself with some of the groups. The individual will become more identified with his/her group if he/she realizes his/her group is superior to "Other groups" through his/her comparing different groups (1986: 7-24).

In the following discussion, the impact of anti-Americanism on European social identity building will be studied in empirical terms. The rising anti-Americanism in Europe from 2002-2004 will be set as the first variable, whose changing tendency can be seen in the rising dissatisfaction with American foreign policy and the slipping American image among individual Europeans (see table 3 and 4).

Insert Table 3 Here

The second variable is the influence of anti-Americanism on European social identity and its variation can be shown in the following tables. When asked to make comparisons between American foreign policies and those of EU, less and less individual Europeans held favorable opinions of the US during this period, while more and more Europeans believed that EU played a positive role (see table 4). In 2004, the European public viewed EU much more favorably than the US in the five comparing items. And this means that with the influence of rising anti-Americanism, more Europeans were inclined to believe that "We (the EU)" was in better performance than "Other"(the US) in world affairs, so it is assumed that the Europeans should be more identified with their group--Europe.

\section{Insert Table 4 Here}

And at the same time, the European public wanted their foreign policies to be more independent from the US and their support of common European foreign and security policies have been greatly increased (table 5 and 6 ).

\section{Insert Table 5 \& 6 Here}

More importantly, in 2003, the European support of common foreign policy and European common security and defense policy reached their peaks since 1995 and 1998 respectively (CEC, 2003: 13). Besides, 83\% of the respondents thought that "when an international crisis occurs, the EU members should agree a common position"; $69 \%$ of them believed that "the EU should have a rapid military reaction force of its own"; $68 \%$ of them supported that "the EU should have its own seat on the UN security council" and even $64 \%$ of them held that "the EU should have its own Foreign Minister, who can be the spokesperson for a common EU position."(CEC, 2003: 16) And all these were related to "the desire of the European population to see the EU speak with a common and united voice." (CEC, 2003: 16) All these made it clear that the European social identity building (at least in the diplomatic affairs) was in dramatic increase. Based on the previous analysis, we can safely conclude 
that there are direct relations between the two variables and that the rising anti-Americanism contributed to the European social identity building.

Since the end of the Cold War, the strategic cooperation between Europe and the US has been in lack of strong support, due to the lack of common enemies. The conflicts between the US and the EU will be frequent if the US sticks to its unilateral policy lines and the anti-Americanism will possibly be on the rise again. However, it needs to be pointed out that the influence of anti-Americanism is not stable as it is vulnerable to the changes of American foreign policies and European internal politics. After 2004, the US tried to repair the injured relations, and the American image rose in some of the EU member countries. Besides, the importance of anti-Americanism in European identity building cannot be exaggerated as the European identity is influenced by many factors and anti-Americanism can only explain a small part of the identity building story. For example, in France where the anti-Americanism was most widely and actively supported, the French public refused the European Constitution in June, 2005. However, this cannot deny the truth that anti-Americanism facilitated the European identity building, but only to show the complexities of European identity building. And it is safe to conclude that the role of anti-Americanism in European identity building can possibly be strengthened and enhanced providing the US strong push of unilateralism in world affairs and lack of common enemies for the two.

\section{References}

Berman, R. (2004). Anti-Americanism in Europe: A Cultural Problem. Stanford: Hoover Institution Press.

Buffon, G. (1807). "Of the Varieties in the Human Species”. Barr's Buffon: Buffon's Natural History Containing A Theory Of The Earth, A General History Of Man, Of the Brute Creation, And Of Vegetables, Minerals, Etc. London: T. Gillet, Volume 4.

Ceaser, J. W. (2003). A genealogy of anti-Americanism. The Public Interest. Summer. [Online] Available: http://www.travelbrochuregraphics.com/extra/a_genealogy_of_antiamericanism.htm.

CEC. (2003). Eurobarometer No. 59. Brussels: European Commission. July. [Online] Available: http://www.gesis.org/en/data_service/eurobarometer/publications/index.htm.

CNN online news. (2003). European Protesters Fill Cities. February 15. Saturday. [Online] Available: http://www.cnn.com/2003/WORLD/meast/02/15/sprj.irq.protests.europe.

Erikson, Erik H. (1963). Childhood and Society. WW.Norton\&Company, Inc.

EU to follow Google's lead with online library. (2005). by out-law.com, Oct. 4, 2005. [Online] Available: http://www.out-law.com/page-6190.

EU: European digital library proposed. (2005). eGovernment News, May 4, 2005. [Online] Available: http://europa.eu.int/idabc/en/document/4239/350.

EU: European library information service launched. (2005). eGovernment News, September 14, 2005. [Online] Available: http://ec.europa.eu/idabc/en/document/4648/330.

Ferguson, Euan. (2003). One million and still they came. The Observer. February 16. [Online] Available: http://www.guardian.co.uk/uk/2003/feb/16/voterapathy.iraq.

Hollander, Paul. (1992). Anti-Americanism: Critiques at Home and Abroad, 1965-1990. New York: Oxford University Press.

Kahn, Dominique Strauss. (2003). Die Geburt einer Nation. Frankfurter Rundschau, 11 March.

Kenrick, Douglas T., Neuberg, Steven L. \& Cialdini, Robert B. (2007). Social Psychology: Goals in Interaction. New York: Person Education, Inc., p.388.

Kohut, A. (2006). America Against the World: How We Are Different and Why We Are Disliked. New York: Henry Holt and Company.

Labi Aisha. (2005). A French Library Leader Urges a European Response. The Chronicle of Higher Education, Vol. 51, Issue. 39, pg.A.27, Jun 3.

Lawday, D. (2001). Un-American activities rule in France. New Statesman, June 18. [Online] Available: http://www.newstatesman.com/200106180023.

Markovits, A. (2005). Anti-Americanism in Europe: From Political Distain to Political Force, Old Europe, New Europe, Core Europe: Transaltantic Relations after the Iraq War. In, eds. Daniel Levy, Max Pensky, John Torpey London: Verso Press. [Online] Available: http://www.ces.columbia.edu/pub/papers/Markovits.pdf.

Pauw, C. (1974). Recherches philosophiques sur les américains. Oeuvres philosophiques, Volume 1. 
Said, E. W. (1994). Orientalism. New York: Random House, Inc.

Tajfel H. \& Turner J.C. (1986). The social identity theory of intergroup behavior, in eds. Worchel S. and Austin L. W., Psychology of Intergroup Relations. Chicago: Nelson Hall.

The Pew Research Center. (2003). America's Image Further Erodes, Europeans Want Weaker Ties. Washington: The Pew Research Center for the People \& the Press, March 14. [Online] Available: http://pewglobal.org/reports/display.php?ReportID=175.

The Pew Research Center. (2004). A Year After Iraq War: Mistrust of America in Europe Ever Higher, Muslim Anger Persists. June, 3. [Online] Available: http://pewglobal.org/reports/display.php?ReportID=206.

\section{Notes}

Note 1. The words "Europe" and "European" in this paper refer to the 15 EU member countries before the enlargement of EU in May, 2004. They are so defined because the newly joined countries, "New Europe", held different attitudes towards the US from the "Old Europe" and the anti-Americanism was not strong in the New Europe.

Note 2. They refer to the libraries in the University of Michigan, Harvard University, Stanford University, The New York Public Library, and Oxford University.

Table 1. The European Union is ... the United States in

\begin{tabular}{|c|c|c|c|c|}
\hline & Ahead & At the same level as & Behind & Don't know \\
\hline $\begin{array}{c}\text { Protection of the } \\
\text { environment }\end{array}$ & $59 \%$ & $18 \%$ & $13 \%$ & $11 \%$ \\
\hline $\begin{array}{c}\text { Fighting social } \\
\text { disparities }\end{array}$ & $53 \%$ & $20 \%$ & $21 \%$ & $13 \%$ \\
\hline $\begin{array}{c}\text { The healthcare } \\
\text { system }\end{array}$ & $51 \%$ & $23 \%$ & $16 \%$ & $14 \%$ \\
\hline $\begin{array}{c}\text { Fighting } \\
\text { discrimination }\end{array}$ & $47 \%$ & $24 \%$ & $20 \%$ & $13 \%$ \\
\hline Education & $42 \%$ & $27 \%$ & $2 \%$ & $16 \%$ \\
\hline $\begin{array}{c}\text { Fighting } \\
\text { unemployment }\end{array}$ & $32 \%$ & & & $13 \%$ \\
\hline
\end{tabular}

(Source: Eurobarometer No.64, October-November, 2006, p145.)

Table 2. Favorable Opinions of the U.S. in Major European Countries (\%)

\begin{tabular}{|c|c|c|c|c|c|c|}
\hline & $1999 / 2000$ & 2002 & 2003 & 2004 & 2005 & 2006 \\
\hline $\begin{array}{c}\text { Great } \\
\text { Britain }\end{array}$ & 83 & 75 & 70 & 58 & 55 & 56 \\
\hline France & 62 & 63 & 43 & 37 & 43 & 39 \\
\hline Germany & 78 & 61 & 45 & 38 & 41 & 37 \\
\hline Spain & 50 & -- & 38 & -- & 41 & 23 \\
\hline
\end{tabular}

(Source: The Pew Global Attitudes Project, June 13, 2006, p1.) 
Table 3. American Image Slips

American Favorability Ratings in Major European Countries: (\%)

\begin{tabular}{|c|c|c|c|c|}
\hline & '99-00 & 2002 & 2003 & 2004 \\
\hline Britain & 83 & 75 & 48 & 58 \\
\hline France & 62 & 63 & 31 & 37 \\
\hline Germany & 78 & 61 & 25 & 38 \\
\hline Italy & 76 & 70 & 34 & -- \\
\hline Spain & 50 & -- & 14 & -- \\
\hline
\end{tabular}

(1999/2000 survey trends provided by Office of Research, U.S. Department of State. Source: The Pew Global Attitudes Project, June 13, 2006, p1.)

Table 4. Positive Role Played the EU and the US in World Affairs

\begin{tabular}{|c|c|c|c|c|}
\hline \multirow{2}{*}{} & \multicolumn{2}{|c|}{ The USA } & \multicolumn{2}{c|}{${\text { The } \mathrm{EU}^{3}}$} \\
\cline { 2 - 5 } & $02 \%$ & $04 \%$ & $03 \%$ & $04 \%$ \\
\hline $\begin{array}{c}\text { The fight against } \\
\text { terrorism }\end{array}$ & $54 \%$ & $39 \%$ & $54 \%$ & $59 \%$ \\
\hline Peace in the world & $32 \%$ & $22 \%$ & $60 \%$ & $61 \%$ \\
\hline $\begin{array}{c}\text { The protection of } \\
\text { environment }\end{array}$ & $16 \%$ & $14 \%$ & $46 \%$ & $58 \%$ \\
\hline $\begin{array}{c}\text { The fights against } \\
\text { poverty in the } \\
\text { world }\end{array}$ & $20 \%$ & $18 \%$ & $36 \%$ & $45 \%$ \\
\hline $\begin{array}{c}\text { The growth of } \\
\text { world economy }\end{array}$ & $38 \%$ & $35 \%$ & $40 \%$ & $49 \%$ \\
\hline
\end{tabular}

(Source: Eurobarometer, No.62, October-November, 2004, p125.)

Table 5. Support for an Independent Foreign Policy

\begin{tabular}{|c|c|c|c|c|}
\hline & Apr. 2002 & Mar. 2003 & May 2003 & Mar. 2004 \\
\hline Britain & $47 \%$ & $48 \%$ & $45 \%$ & $56 \%$ \\
\hline France & $60 \%$ & $67 \%$ & $76 \%$ & $75 \%$ \\
\hline Germany & $51 \%$ & $52 \%$ & $57 \%$ & $63 \%$ \\
\hline Italy & $59 \%$ & $63 \%$ & --- & --- \\
\hline Spain & --- & $60 \%$ & --- & -- \\
\hline
\end{tabular}

(Source: The Pew Global Attitudes Project, March, 2004, p1 \& p8.)

Table 6. Decisions Concerning European Defense Policy Should Be Made By?

(Surveyed in the EU 15)

\begin{tabular}{|c|c|c|}
\hline & Autumn 02' & Spring 03' \\
\hline The EU & $44 \%$ & $49 \%$ \\
\hline NATO & $21 \%$ & $14 \%$ \\
\hline National Governments & $21 \%$ & $21 \%$ \\
\hline Don't know & $14 \%$ & $16 \%$ \\
\hline
\end{tabular}

(Source: Eurobarometer No.59, March-April, 2003, p16.) 